\title{
Biodiversity offsets for offshore wind farm projects: The current situation in Europe
}

\author{
Anne-Charlotte Vaissière ${ }^{a, *}$, Harold Levrel $^{a}$, Sylvain Pioch ${ }^{b}$, Antoine Carlier $^{c}$
}

\author{
a IFREMER, UMR AMURE, Marine Economics Unit, ZI Pointe du Diable, CS 10070, F-29280 Plouzané, France \\ b University of Montpellier 3, Bio-geography, CNRS-UPV, UMR 5175 CEFE, Route de Mende, F-34199 \\ Montpellier, Cedex 5, France \\ c IFREMER, DYNECO_Ecologie Benthique, ZI Pointe du Diable, CS 10070, F-29280 Plouzané, France \\ *: Corresponding author : Anne-Charlotte Vaissière, tel.: +3329822 4040 ; mob.: +33616 871535 ; \\ email addresses : anne.charlotte.vaissiere@ifremer.fr ; ac.vaissiere@gmail.com
}

\begin{abstract}
:
The European Union's energy policy aims to increase the proportion of energy derived from renewable sources in Europe. Marine renewable energy, offshore wind energy especially, contributes to the renewable energy mix. Offshore wind farms appear to be clean, and are supported by governments and NGOs as a way to reduce the use of conventional energy resources and thus decrease greenhouse gas emissions. However, developing infrastructure in marine areas can impact marine ecosystems. European directives ask offshore wind farm developers to carry out an Environmental Impact Assessment (EIA) including a mitigation hierarchy, i.e. envisaging measures that would avoid, reduce, and if possible offset significant adverse effects on ecosystems and human activities. This paper reviews EIA reports from seven European countries and is focused on impacts on the open water marine environment. According to the reports, measures have been taken for avoiding and reducing impacts, so there should be no significant negative residual impacts and hence no need of offsets. But the mitigation hierarchy for ecological impacts seems to have been incompletely implemented, because it is unlikely that there are no significant residual impacts. The paper proposes some technical and ecological explanations, followed by some governance and social explanations, for the absence of biodiversity offsets.
\end{abstract}

\section{Highlights}

European bottom-fixed offshore wind farms EIA reports have been collected. Ecological mitigation measures described in the reports have been listed. The mitigation hierarchy has been incompletely implemented. Only measures for avoidance and reduction of the marine impacts are proposed. This paper discusses the possible explanations for the absence of biodiversity offsets.

Keywords: Mitigation hierarchy ; Offshore wind farms ; EIA 


\section{Introduction}

Directive $2009 / 28 / E C^{1}$ on renewable energy, signed by Member States of the EU in December 2010, sets a target of a $20 \%$ share of energy from renewable sources by 2020 . Among types of marine renewable energy, cumulative offshore wind power capacity progressed from $0 \mathrm{MW}$ in 1990 to $4995 \mathrm{MW}$ at the end of 2012, and is targeted to reach more than $32,200 \mathrm{MW}$ in 2020 [1]. This policy is strongly supported by governments and NGOs in order to reduce the use of conventional energy resources, thus decreasing greenhouse gas emissions to satisfy Kyoto protocol targets. Construction efforts are still needed and the amount of investment needed to reach this goal is clearly a challenge for the future.

At the same time, the exploration, construction, production, and decommissioning of infrastructures in marine areas all have temporary or permanent negative impacts on marine ecosystems: destruction of seabeds, disturbance of fish populations and marine mammals, collisions with seabirds or degradation of natural landscapes, for example. Studies and reports describing the impacts of offshore wind farms on the environment are numerous. The following is a brief review of the main ones. A much-cited grey literature report [2] deals with the Horns Rev and Nysted farms, which were the biggest until 2010 (Appendix). Three other well-known documents, two co-produced by Danish developers and the state of Denmark ([3] and its update [4]) and the other by the Danish Energy Authority alone [5], present general information on the impacts of offshore wind farm projects on natural environment. During the 2009-2012 period, reports were produced by the Royal Belgian Institute of Natural Sciences (RBINS) and the Management Unit of the North Sea Mathematical Models (MUMM) about offshore wind farms in the Belgian part of the North Sea [6] [7] [8] [9]. Under the Sixth Framework Program (2002-2006), the European Commission financed the Concerted Action for Offshore Wind Energy Deployment and published a description of the current state of offshore wind energy in Europe, dealing with environmental issues among other things [10] [11] [12] [13]. In 2010 the IUCN published a report called Greening Blue Energy: Identifying and managing the biodiversity risks and opportunities of off shore renewable energy" [14]. A great deal of the scientific literature deals with specific environmental impacts or phases of the project; these are not cited in this paper. Some of them have offered a more general review of the impacts of marine renewable energies, e.g. [15] [16] [17], or of offshore wind farms, e.g. [18] [19] [20] based on the relevant scientific literature.

The legal framework dealing with the environmental impact of offshore wind farms is the Environmental Impact Assessment (EIA) process (section 3.1). It requires developers to produce an EIA report outlining measures that would avoid, reduce and, if possible, offset significant adverse effects. In other words, they have to follow a mitigation hierarchy.

In 2003, Kristina Rundcrantz and Erik Skärbäck wrote an article about the EIA in several European countries, noting that $\mathrm{If}$ compensation measures are proposed, described and analyzed in a good way in the EIA this will probably make it easier for the measures to be implemented in the project" [21]. What is the situation now, ten years later?

Unfortunately, none of the documents cited above have covered in detail the information available in the EIA reports for offshore wind farms. Apparently, no recent article describes how the marine environment and biodiversity in open water are currently taken into account in European offshore wind farm development, nor how the mitigation hierarchy is being implemented. Feedback from countries where these projects began more than twenty years ago, with the Vindeby offshore wind farm built in Denmark in 1991, would be useful for other countries that expect soon to develop offshore wind farms. Today, offshore wind farms are

\footnotetext{
${ }^{1}$ Directive 2009/28/EC of the European Parliament and of the Council of 23 April 2009 on the promotion of the use of energy from renewable sources and amending and subsequently
} 
only deployed in Northern European countries. This paper reviews the legal framework and the measures for avoiding or reducing the impact on marine ecosystems that have been proposed in the EIA reports. The discussion focuses on some measures that have been presented as biodiversity offsets and proposes a possible explanation of the absence of marine biodiversity offsets in open water.

Lastly, it is important to define precisely the concept of biodiversity offset". The definition used in this paper is: Biodiversity offsets [are] conservation actions intended to compensate for the residual, unavoidable harm to biodiversity caused by development projects, so as to ensure no net loss of biodiversity. Before developers contemplate offsets, they should have first sought to avoid and minimise harm to biodiversity" [22]. The term -ompensatory measure" or -compensation measure" is often used. Biodiversity offsets" corresponds to ecological compensatory/compensation measures"; -mitigation" is a more general term that includes all the steps of the mitigation hierarchy (avoid, reduce, offset).

\section{Materials and methods}

The information sources on offshore marine renewable energy mainly used here are: the European Wind Energy Association, the various national Wind Energy Associations, and the websites Thewindpower.com and 4coffshore.com; additional data have been collected from each wind farm website. This paper presents an outline of the current situation as of August 2013.

\subsection{Choice of sample}

Usually marine renewable energy projects are divided into those accepted," planned," under construction," and in production." All the selected offshore wind farms for this paper are European fixed-bottom wind farms in production" or under construction". The farms for which construction has not yet begun (some under construction," planned," and accepted") have not been selected because claims against the projects and construction delays may still prevent actual construction.

Table 1: Number of fixed-bottom offshore wind farms in production and under construction in the European Union, by country, as of August 1st 2013

\begin{tabular}{|l|l|l|}
\hline Country & Number of farms \\
\hline & in production & $\begin{array}{l}\text { under } \\
\text { construction }\end{array}$ \\
\hline UK & 15 & 4 \\
\hline Denmark & 10 & 0 \\
\hline Sweden & 4 & 1 \\
\hline Germany & 2 & 8 \\
\hline Belgium & 3 & 2 \\
\hline Netherlands & 2 & 0 \\
\hline Ireland & 1 & 0 \\
\hline Total & $\mathbf{3 7}$ & $\mathbf{1 5}$ \\
\hline
\end{tabular}

Some wind farms were considered as not relevant for this study for the three following reasons:

- Size: for small demonstration farms with fewer than 4 turbines the EIA process is almost never mandatory.

- Location: some nearshore farms can be considered as onshore because they are installed on artificial islands and often linked to the mainland by spits of land or bridges (e.g. the 
Rønland wind farm in Denmark). Some are installed in terrestrial areas or areas other than the open sea, such as freshwater lakes, estuaries, and harbors (e.g. the Irene Vorrink wind farm in The Netherlands).

- Technology: floating wind farms were not included because they are still at the prototype stage.

This left 52 fixed-bottom wind farms for study. On August 1st 2013, 37 farms are in production in Europe and 15 more are under construction (Table 1Erreur ! Source du renvoi introuvable.).

\subsection{Data collected}

\subsubsection{Legal framework and obligations in Europe}

Information has been gathered on how Member States have transposed and enforced the EIA directive for offshore wind farms, and on national laws (where these exist) covering offshore wind farms and the mitigation hierarchy. The main source used for information on national legal frameworks is the European Commission website. Members of the EIA/SEA Expert Group of the European Commission have been contacted. The paper mainly focuses on the transposition of the EIA Directive into national law, and does not describe the complete administrative and legal framework for offshore wind farms.

2.2.2. Description of potential impacts on marine ecosystems and related mitigation measures in EIA reports

Studying the EIA reports appeared to be the most appropriate and effective way to collect information about the measures for avoiding, reducing, or offsetting impacts. According to EU legislation, the EIA reports have to be made available in the public domain. In some countries such as the UK, Denmark, and Belgium the main sections of the EIA reports were readily accessible on the websites of wind farm projects, government institutions, and local authorities. In contrast, countries such as Germany and Sweden do not put all their EIA reports online. In this case, requests were sent to researchers working on these topics, wind farm developer employees, and government employees. Different languages are used in these reports, although many recent ones have at least a summary of the EIA or a nontechnical summary translated into British English. Only one developer with an EIA report refused to share it.

Out of the 52 offshore wind farms studied, 34 complete reports were collected (27 found online and 7 acquired in response to a request). Ten partial reports were collected (summary of the EIA, non-technical summary, or the project approval). However, 8 reports were not found, mostly because hardcopy versions of the report exist in the archives of the relevant ministries, but copies could not be provided (older projects, implemented before 2003). For details, see the Appendix.

Information about the most frequently described impacts and measures for avoiding, reducing, or offsetting impacts during the construction, operation, and decommissioning phases has been extracted from the EIA reports and presented in Electronic Appendices 1 and 2. The focus is especially on identifying biodiversity impacts and measures on the offshore environment (EIA reports, almost purely British ones, also deal with the onshore environment). The descriptions of impacts and related measures from the EIA reports have been summarized in section 3.2. 


\section{Results}

\subsection{Legal framework and obligations in Europe}

The directive 2011/92/EU ${ }^{2}$, which is the codification of the directive $85 / 337 / \mathrm{EEC}^{3}$ and its two amendments $\left(97 / 11 / \mathrm{EC}^{4}\right.$ and $\left.2003 / 35 / E C^{5}\right)$, specifies that

- For the projects listed in Annex I, an EIA is mandatory for all the Member States.

- For the projects listed in Annex II, the Member States have to determine, either through a case-by-case examination or through thresholds or criteria set by the member state, whether an EIA is mandatory. They also can transfer projects from Annex II to Annex I.

Offshore wind farms are specifically mentioned in Annex II (the term wind farms" appears in Annex II with the 97/11/EC amendment). Member States have defined thresholds and criteria to determine if an EIA is mandatory for offshore wind power projects (Table 2).

Table 2: Thresholds and criteria for wind farms in the seven Member States studied (source: national law texts and [23])

\begin{tabular}{|c|c|}
\hline Country & Thresholds and criteria \\
\hline UK & $\begin{array}{l}\text { Indicative threshold: } \geq 5 \text { turbines or }>5 \mathrm{MW} \text { capacity (case-by-case } \\
\text { examination above this threshold) } \\
\text { Exclusive threshold : } \leq 2 \text { turbines and hub height or height of any other } \\
\text { structure }<15 \mathrm{~m} \\
\text { When an offshore wind farm capacity is more than } 100 \mathrm{MW} \text { and is }(\mathrm{a}) \text { in } \\
\text { waters in or adjacent to England or Wales up to the seaward limits of the } \\
\text { territorial sea, or (b) in a Renewable Energy Zone, except any part of a } \\
\text { Renewable Energy Zone in relation to which the Scottish Ministers have } \\
\text { functions, a Development Consent Order (DCO) from the Infrastructure } \\
\text { Planning Commission is required. }\end{array}$ \\
\hline Denmark & $\begin{array}{l}\text { Id : }>80 \text { m height or } \geq 3 \text { turbines } \\
\text { Id: case-by-case examination }\end{array}$ \\
\hline Sweden & Mandatory threshold : > $10 \mathrm{MW}$ \\
\hline Gern & $\begin{array}{l}\text { Mandatory threshold: } \geq 35 \mathrm{~m} \text { height or } \geq 10 \mathrm{MW} \text { capacity and } \geq 20 \text { turbines. } \\
\text { Additional indicative threshold: } \geq 35 \mathrm{~m} \text { height or } \geq 10 \mathrm{MW} \text { capacity and } \geq 6 \text { to } 19 \\
\text { turbines ( } 3 \text { to } 5 \text { turbines in sensitive areas) }\end{array}$ \\
\hline Belg & $\begin{array}{l}\text { Wallonia: } \\
\text { Mandatory threshold: } \geq 7 \mathrm{MW} \text { capacity } \\
\text { Below this threshold: EIA is not required. } \\
\text { Other regions: nc }\end{array}$ \\
\hline Netherlands & $\begin{array}{l}\text { Indicative threshold: }>10 \text { MW capacity or } \geq 10 \text { turbines } \\
\text { Above the threshold: case-by-case examination } \\
\text { Below the threshold: EIA is not required }\end{array}$ \\
\hline Ireland & $\begin{array}{l}\text { Mandatory threshold : }>5 \mathrm{MW} \text { or } \geq 5 \text { turbines } \\
\text { But a case by case examination can be required if the Competent Authority } \\
\text { considers that significant environmental effects are likely }\end{array}$ \\
\hline
\end{tabular}

\footnotetext{
${ }^{2}$ The Directive 2011/92/EU of the European Parliament and of the Council of 13 December 2011 on the assessment of the effects of certain public and private projects on the environment.

${ }^{3}$ The Council Directive 85/337/EEC of 27 June 1985 on the assessment of the effects of certain public and private projects on the environment.

${ }^{4}$ The Council Directive 97/11/EC of 3 March 1997 amending Directive 85/337/EEC on the assessment of the effects of certain public and private projects on the environment.

${ }^{5}$ The Directive 2003/35/EC of the European Parliament and of the Council of 26 May 2003 providing for public participation in respect of the drawing up of certain plans and programs relating to the environment and amending with regard to public participation and access to justice Council Directives 85/337/EEC and 96/61/EC.
} 
Some Member States already had EIA legislation in place; all the Member States had to transpose Directive 85/337/EEC before March 7th 1988. Sweden and Finland joined the European Union in 1995, so had to transpose it before January 1st 1995. However, some Member States delayed transposition, or included offshore wind farms in national legislation later on. For instance, in Finland wind farms were only taken into account in 2011 in a decree $^{6}$ that states that wind farms fall under the EIA law (1) when the farm is composed of ten or more wind turbines or (2) when the total power is at least $30 \mathrm{MW}$. The EIA was thus not mandatory for the only offshore wind farm in Finland, built in 2008. Lastly, some Member States did not meet the requirements of the directive fully and had to answer to the European Commission. For example, in a decision of June 28th 2006, the European Commission gave formal notice to the Belgian authorities with Impact - Non-conform transposition of the EIA Directive" (case 2006/22697). The European Commission decision of October 16th 2008 issued a reasoned opinion because the Belgian authorities did not respond correctly to the formal notice.

Some Member States have adjusted the legal framework to make it more flexible by establishing national laws that facilitate the further development of offshore wind farms. In Germany, an EIA is mandatory for offshore wind farms (Environmental Impact Assessment $\left.A c t^{8}\right)$. According to paragraph $17(10)$ of the Act on Nature Conservation and Landscape Management ${ }^{9}$, developers must accept the obligation to compensate for environmental impacts. Article 15 describes the compensation obligation. But paragraph 56 (2) specifies that offshore wind farms located in the Exclusive Economic Zone (EEZ) which receive building permits before January 1st 2017 are not affected by article 15. Consequently, biodiversity offsets for offshore wind farms in the EEZ are not mandatory for the moment in Germany.

Legislation about potential impacts on Natura 2000 zones consists of the Birds Directive ${ }^{10}$ and the Habitats Directive ${ }^{11}$ that Member States must transpose into national law. If a site is part of the Natura 2000 network, developers have to make an appropriate assessment of the implications for the site. If negative impacts with no alternatives are identified, the Member State shall take all compensatory measures necessary to ensure that the overall coherence of Natura 2000 is protected" (Article 6.4 of the Habitats Directive).

\subsection{Description of the main potential impacts on marine ecosystems and related mitigation measures in the EIA reports}

Of the different phases of a wind farm project, the exploration phase is hardly ever addressed, the construction and operation phases are always presented, and the

6 (359/2011) Valtioneuvoston asetus ympäristövaikutusten arviointimenettelystä annetun valtioneuvoston asetuksen 6 §:n muuttamisesta [in Finnish and Swedish only]. Legal act: Valtioneuvoston asetus, Number: 359/2011; Official Journal: Suomen Saadoskokoelma (SK), Number: 359/2011, Publication date: 21/04/2011, came into force: 01/06/2011. The paragraph about wind farms is $6 \S 7(\mathrm{e})$.

${ }^{7} \mathrm{http}: / /$ ec.europa.eu/eu_law/infringements/infringements_decisions_en.htm

${ }^{8}$ Environmental Impact Assessment Act [Gesetz über die Umweltverträglichkeitsprüfung UVPG] as published in the announcement of September 5th 2001 (BGBI. I p. 2350).

${ }_{9}$ Act on Nature Conservation and Landscape Management (Federal Nature Conservation Act - BNatSchG) of 29 July 2009.

${ }^{10}$ Directive 2009/147/EC of the European Parliament and of the Council of 30 November 2009 on the conservation of wild birds (codified version of Directive 79/409/EEC as amended).

${ }^{11}$ Habitats Directive: Council Directive 92/43/EEC of 21 May 1992 on the conservation of natural habitats and of wild fauna and flora. 
decommissioning phase is almost always discussed though more briefly. The environmental topics discussed include soil, water, benthos, fish, birds, and marine mammals.

\subsubsection{Construction phase}

During the construction phase, impacts in the wind farm area and the immediate surroundings are expected to be more numerous and intense but of a shorter duration than the impacts during the operation phase. The impacts are described as minor during the construction phase, except for the destruction of seabed and benthos when turbines are installed. The main impacts described are listed in Electronic Appendix 1 along with the related measures proposed for avoiding or reducing them, and the explanations given by the developers.

\section{Seabed and benthos}

The seabed is compacted and made denser by the construction work. The benthos (invertebrates like worms and shellfish), seagrass (if any), and species living on the bed (e.g. starfish, crabs) are affected when the seabed is dredged before digging into it and during the cable installation that links offshore turbines to onshore substations. Turbidity and material from stirred-up sediment can impact the benthos and filter feeders (the filter system of filter feeders is locked).

In 15 of the reports, the loss of seabed corresponding to the land use of piles (and scour protection when needed) is often considered negligible in comparison with the size of the seabed as a whole and the surface area of the wind farms. Additionally, 16 reports note that there are not many species in these sandy areas or that the species are not threatened. Most of the farms (20) claim that the benthos is resilient: seagrass recovers after a few years and there is a rapid recolonization and migration of animals from surrounding areas. In 7 of the reports, some species are described as being used to a changing dynamic environment and to high turbidity (e.g. polychaete worms and crustaceans). However, one reduction measure proposed in 10 reports is the use of a plough instead of water jetting for the cable installation, because it affects a smaller surface area and amount of sediment and keeps turbidity to a minimum. Five reports suggest that the reef effect around turbines is a positive outcome that offsets the loss of seabed. The reef effect is the creation of an artificial reef leading to an increase of biodiversity [14] [19] [20] [24] [25].

\section{Fish}

Turbidity and material from stirred-up sediment can impact fish. Suspended particles increase turbidity and reduce light penetration, and in consequence photosynthesis decreases and the trophic chain balance is broken. Underwater noise and vibration result from dredging and pile-driving: fish are disturbed and can be injured (hearing damage, death, distorted behavior). Developers claim that these impacts are minor and temporary and vary from species to species. Some migratory fish may be disturbed.

Most of the reports say that fish usually avoid the site during construction work. Eleven of the reports propose to avoid important stages in the fish life-cycle (mostly spawning). In 17 of the reports an acoustic startle system and/or soft start procedure during pile-driving are recommended to drive fish out of the construction zone, meaning that they are not impacted by turbidity, noise, etc. In 14 reports it is claimed that this measure can frighten fish but that they usually come back to the site when construction is finished.

\section{Marine mammals}

Noise and vibration can affect marine mammals' health if they are on the site (hearing damage). Moreover, because fish are also leaving the site, food resources for marine mammals can decrease temporarily.

Most of the reports note that marine mammals usually avoid the site during construction work. Thirteen reports propose avoiding periods of high frequentation by marine mammals 
(breeding and molting) or limiting disturbance when mammals are present. A Marine Mammals Observer can be used to determine if activity must be temporarily halted because of the presence of marine mammals. In 24 of the reports an acoustic startle system and/or a soft start procedure during pile-driving are recommended to drive marine mammals out of the construction zone. At least 5 reports propose the use of an air bubble curtain so that animals will not be impacted by noise and vibration. Nineteen reports note that this measure can frighten marine mammals but that they usually return fairly quickly after the construction work (even between pile-driving sessions) because they become accustomed to it. The noise and vibration are also quite comparable to existing activity in the region (marine traffic, dredging, oil platforms, etc.) according to at least 4 reports. Lastly, for 7 farms in the United Kingdom, marine mammals are said to be not very numerous, so there should be no significant impact in their case.

\section{Birds: Resting, foraging, and migration}

The distinction between foraging and migrating birds is not made systematically. However, it should not be expected that different species will have the same reaction to construction work. Birds may be disturbed by the presence of vessels involved in construction activity (noise, vibration, lighting), with avoidance of the site as the main result. Some reports note a barrier effect and collision risk even during the construction phase.

There are 29 reports that propose avoiding periods of high frequentation by birds on the site. However, 4 reports note that sediments that are stirred up or other disturbance of the fish might be a significant factor in the availability of food resources. If major impacts emerge during the construction phase, 2 Belgian developers propose creating or extending protection zones for birds, though this would be on shore. Lastly, 11 farms report that birds are not very numerous so there should be no significant impact in their case.

\subsubsection{Operation phase}

Compared to the construction phase, the impacts in the operation phase will be permanent over the entire lifetime of the wind farm, but they are very localized and limited. However, maintenance activity can temporarily impact the marine environment. The main impacts reported are listed in Electronic Appendix 2 with the related measures proposed for avoiding and reducing them; and explanations given by the developers.

\section{Seabed and benthos}

1/ Changes in the location of turbines:

The soft bottom is transformed to hard bottom due to the installation of the foundations and piles for the turbines. This impact is mostly not seen as negative (artificial reef). Few farms mention the risk of disturbing natural habitats and introducing invasive species.

No mitigation measures are proposed. This reef effect, noted in 39 reports, is identified as positive because biodiversity and habitat complexity are expected to increase. Small plants, common mussels, and other marine life colonize this new substrate and attract fish.

\section{2/ Changes around turbines:}

There is a risk of scouring around the base of the turbines due to very local hydrodynamic changes. Hydro-sedimentological regimes can be locally disturbed, but there are never any significant changes farther away from the turbines and their scour protections. This effect is found around transportation cables according to 5 reports. There are no significant effects on the total sediment movement already associated with the sandbanks.

Scour protections, such as large rocks, installed around the foundations of the turbines limit the sand transportation close to the turbines to a minimum and reduce the effect of sediment erosion (claimed in 35 reports). Moreover, the scour protections are said to act like artificial reefs (in 8 reports), which is identified as a positive effect. Reports highlight some particular features that enhance the reef effect: Arklow Bank (Ireland) proposes using the artificial reef as a criterion of development if gravity foundations are chosen; Prinses Amalia (Netherlands) 
proposes to install scour protections with caves in the top layer so that crustaceans (edible crab and perhaps North Sea lobster) and fish (eel) can be established; Gunfleet Sands and West of Duddon Sands (UK) plan to use frond mats as an anti-scour solution that would also be colonized; London Array (UK) proposed varying sizes of rock.

\section{Fish}

Underwater noise and vibration from the turbine rotors disturb fish. They can also be sensitive to the electromagnetic field generated by the cables. These two impacts are not well described at the moment but may represent a health risk for fish and will probably lead them to avoid offshore wind farms. The impact is likely to vary depending on the species, and some migratory fish may be disturbed.

In 11 reports it is claimed that fish will get accustomed to noise and vibration. In 19 reports, the reef effect is expected to benefit the fish by providing them with more food resources: they are attracted by the colonized turbine piles and scour foundations (this is called the fish aggregating device effect" in some reports). A ban on fishing is proposed around at least 16 wind farms, which ought to create a reserve effect on fish populations. The reserve effect is the protection of a zone by prohibiting extracting activities like fishing [17]. Generally, very little is known about the impact of electromagnetic fields. Twelve reports from British wind farms propose to bury, insulate, or armor the cables so as to reduce the magnitude of their electromagnetic field.

\section{Marine mammals}

Noise, vibration, and the presence of the turbines may disturb marine mammals (who also use sounds to communicate) and make them avoid the site. Marine mammals can also be sensitive to the electromagnetic field generated by the cables.

Few mitigation measures are proposed but positive" impacts are underlined. The reef effect is expected to provide more food resources for marine mammals (more fish are attracted) according to 17 reports. According to 3 reports, some may even be attracted to the site by curiosity or because they benefit from a place offering food, rest, and refuge. Generally, very little is known about the impact of electromagnetic fields. Mitigation measures that would reduce the electromagnetic field, like those for fish, are proposed in only 2 reports.

\section{Birds: Resting, foraging, and migration}

The distinction between foraging and migrating birds is not made systematically. It can be expected that birds will be disturbed by the presence of the turbines. Birds will probably avoid a site that had been useful for resting or foraging, especially when the wind turbines are rotating. The barrier effect results in a shift of the flight path to avoid the farm, as though it was a barrier. There is a collision risk with the wind turbines that can injure or kill the birds, the risk being greatest during poor visibility periods (night, fog, or bad weather). Legally required lighting for ship and plane safety may attract birds to the wind farms and increase the collision risk.

The reef effect and the reserve effect are expected to provide more food resources for birds (e.g. fish and mussels) according to 13 reports. In order to reduce collision risk, 6 reports propose stopping the turbines during migration and/or bad weather, and 8 others propose reducing the amount of lighting (while still remaining within regulatory levels for aviation and navigational requirements) since it may attract birds, especially land birds. In contrast, 2 farms mentioned the use of lighting as a way to make the turbines more visible. Positioning the turbines in different patterns (in groups, rows) or taking account of the prevailing wind and bird flight paths in order to minimize the barrier effect is discussed in 7 reports; however, this belongs in the design phase. Some mitigation measures are not yet planned but would be discussed if significant impacts are detected during the operation phase. 


\subsubsection{Decommissioning phase}

To date no farms in Europe have actually reached the decommissioning phase, but some negative impacts can be expected to occur during it. These are described as similar to the impacts occurring during the construction phase. Moreover, the complete removal of piles, scour protections, and cables might have an adverse impact, as new habitats associated with these underwater structures would be lost, resulting in less diversity. However, some EIA reports describe plans to retain the foundations of the turbines and to leave the buried cables in place to avoid this loss of artificial habitat.

Some reports note that the section on decommissioning is less developed because this will occur after the lifetime of the project. By then, knowledge and techniques should be improved, and the best solutions available at that time will be adopted.

\subsubsection{Principal observations}

The main result of the present study is that European offshore wind farm developers have not implemented ecological offsets for offshore impacts: developers argue that ecological offsets are not necessary because residual impacts are non-significant. Some measures presented as biodiversity offsets are questionable (section 4.1.), such as onshore measures or measures not directly linked to the wind farm impacts, positive effects of the wind farm on marine environment, and monitoring reports. At least one report (Prinses Amalia wind farm in the Netherlands) raised the possibility of monetary mitigation measures; here the lack of equivalency is clear.

In the reports, potential avoiding, reducing, or offsetting measures are grouped together as mitigation measures and not broken down. These mitigation measures are usually proposed in the sections describing the impacts, but in a minority of cases presented separately at the end of the report. Developers often describe environmental impacts without being sure of their intensity or the real effect on the flora and fauna. Impacts are described in varying degrees of detail, by genus or by species. When impacts are described by species, Electronic Appendices 1 and 2 do not go into detail unless there is a focus on a particularly affected species. Some reports present different scenarios for impacts, with a best-case scenario but also a worst-case scenario, in which the effect on the ecosystem is greatest. When decisions are still to be made (on turbine foundations, for instance), the various possible consequences for marine ecosystems are also presented, and the developer identifies the most likely scenario and decision, with related economic, technical, and ecological criteria.

Developers generally address the potential cumulative impacts of multiple wind farms adjacent to each other (35 of the 44 reports) and of multiple turbines in a single array (10 of the 44 reports). These impacts mainly concern avifauna and seabed movement. Since few cases of wind farms positioned very close together exist, and impacts are almost inevitable at the turbine level, developers soon draw the conclusion that wind farms and turbines are spaced far enough apart to be considered as independent units. For 31 reports, as with the impacts described in section 3.2.1 to 3.2.3, the predicted impacts are said to be negligible to minor. Ten reports also emphasize that they do not have enough knowledge to predict cumulative impacts during the construction phase of their wind farms at the same time as another wind farm or other marine project, so they usually plan to schedule their construction to avoid this situation.

There are three possible situations presented in the EIA reports:

$1 /$ No impact or non-significant impact: generally no measures are proposed, though sometimes a justification is given. 
2/ Significant negative impact: usually seen as very low to moderate and geographically limited.

Either a justification is given or mitigation measures are proposed (these measures would transform the significant negative impact into a low or non-significant one):

- Scheduling: avoid sensitive periods for marine ecosystems or reduce construction and maintenance work during these periods.

- Location planning.

- Other ad hoc mitigation measures are proposed to deal with a specific probable impact: for instance, scour protections limit the erosion around the piles of the turbines and the cables.

3/ Significant positive impact (most often reef or reserve effect): this is mentioned in order to counterbalance a specific negative significant impact or more generally to offset negative residual impacts.

The justifications offered in cases $1 /$ and $2 /$ are technical and ecological explanations. Table 3 presents a count of these explanations in the EIA reports that are also discussed in section 4.3.1. The two most common explanations are that the significance and the magnitude of the impact are low and/or acceptable (40/44) and that positive impacts are greater than negative ones (42/44). The reef effect is always presented as an offset for a great number of negative impacts, such as the transformation of a soft bottom into a hard bottom and the disturbance of fish, marine mammals, and birds.

Table 3: Occurrence of technical and ecological explanations of the absence of biodiversity offsets in the EIA reports

\begin{tabular}{|l|l|}
\hline $\begin{array}{l}\text { Technical and ecological explanations of the } \\
\text { absence of biodiversity offsets }\end{array}$ & $\begin{array}{l}\text { Number of ElA reports using these } \\
\text { justifications (on the 44 collected reports) }\end{array}$ \\
\hline No significant negative residual impacts & 40 \\
\hline Positive impacts greater than negative impacts & $\begin{array}{l}42 \text { (reef effect (42), reserve effect (18), more } \\
\text { food resource (13), other (6)) }\end{array}$ \\
\hline $\begin{array}{l}\text { Negative impacts could be worse than other } \\
\text { activities }\end{array}$ & 23 \\
\hline The resilience theory & 21 \\
\hline Poor knowledge of the marine environment & 22 \\
\hline $\begin{array}{l}\text { Unknown or expensive techniques for marine } \\
\text { ecological offsets }\end{array}$ & $\begin{array}{l}\text { These arguments are almost never included } \\
\text { in the EIA reports probably for strategic } \\
\text { reasons }\end{array}$ \\
\hline
\end{tabular}

More generally, the introductions and conclusions of the reports stress that offshore wind power plays a significant role in reducing greenhouse gas emissions and providing direct economic benefits to local communities. The fact that offshore wind power development, by displacing fossil fuels, could reduce the impact of climate change on marine mammals, fish, and sea birds, for instance by mitigating ocean acidification, is hardly ever mentioned.

A minority of EIA reports include the geographic location planning discussed during the design phase of the project, in which the siting of the farm is decided. This is the first step in avoiding impacts and thus implementing the start of the mitigation hierarchy [2] [11] [26]. This might explain why the reports list more measures for reducing impacts than avoiding them. Developers avoid sensitive areas of high biodiversity, richness, or abundance, or protected areas like Natura 2000 zones, SPAs (Special Protection Areas), and Ramsar sites. For instance, to avoid the barrier effect and collision risk, development zones are chosen away from flyways. The only elements of location planning frequently discussed in the reports are alternative cable routes and the micro-siting of turbines in cases where developers seek to locate each individual turbine appropriately on the site. 


\section{Discussion}

\subsection{Measures presented as biodiversity offsets}

Some measures for offsetting environmental residual impacts are presented in the EIA reports, but their equivalency and appropriateness need to be examined.

First, some onshore measures are proposed to offset offshore impacts. For instance, the Netherlands government asked the Egmond aan Zee offshore wind farm (Netherlands) for a -compensation plan for nature value" in order to offset the possible impact on the marine environment, in response to two appeals brought by an environmental association and an association protesting against the farm. The cost of the plan represented $0.2 \%$ of the total cost of the project. The six proposed measures were:

1. Expansion of De Putten bird reserve for coastal and migratory birds.

2. Fund for the benefit of (migratory) birds and marine organisms.

3. Decontaminating a former transmitting station for the benefit of the dune landscape.

4. Nature restoration of wet dune valley near Diederik parking lot at Egmond-Binnen.

5. A documentary film on nature and marine reserves in the North Sea to emphasize the beauty of the sea.

6. Support for initiative for fishing for litter.

There is a problem of equivalency here. Onshore measures are proposed for offshore impacts, and land-based, even coastal, functions are not the same as marine ones. Some measures address impacts other than those of the wind farm project.

Second, developers present positive impacts as offsetting the negative residual impacts of the farms. However, neither the amount of loss of ecosystem functions due to negative impacts nor the amount of gain of ecosystem functions due to positive impacts is estimated. These measures" are not calculated and implemented to offset the impact; they are -consequences" rather than real measures. For example, the Middelgrunden EIA report (Denmark) notes that the operation phase of the farm will disturb resting and foraging birds and will force them to keep at a distance from the turbines for resting and foraging. It then claims that this negative impact can be counterbalanced by a positive one: mollusks growing on the foundations will supply food, for example for diving ducks. The equivalency here is too weak. The impacted birds will not come around the farm any longer, and the compensated birds belong only to some species (diving ducks). Moreover, it is still a matter of debate whether the reef effect or the reserve effect are truly positive. Lastly, whether the impact is positive or negative is a question of interpretation or of perception [15], especially in the case of unknown, not properly explained, or not monitored impacts. The precautionary principle is hardly ever mentioned in the EIA reports.

Third, when impacts are little known or unknown, some developers propose monitoring as a biodiversity offset. Monitoring may well have an indirect positive effect on the environment by improving scientific knowledge of it. However, it is not an offset, because impact still occurs. Monitoring is necessary, but ought not to be presented as a biodiversity offset.

\subsection{Different assessments of the impacts}

There are some differences between the assessments of the impacts collected in the EIA reports and those listed in the grey and scientific literature. EIA reports are likely to be less alarming than grey and scientific literature; one might ask whether developers tend to highlight the positive effect of offshore wind farms for strategic reasons. The grey and scientific literature does seem to be more alarming: negative impacts are mentioned and it seems less certain that they are non-significant. Moreover, they indicate that they have only 
recorded observations over the short term, insufficient to support all the desired conclusions, and that observations in one location cannot be directly extrapolated to estimate environmental impacts in other locations. They also admit that the scientific and social thresholds of significance relative to the endangering of the marine environment are very difficult to define [18].

The reef effect can be offered as an example of the differences between these two sources of information:

- In the EIA reports the reef effect is almost always presented as positive and expected to offset a great number of negative impacts such as the transformation of a soft bottom into a hard bottom and the disturbance of fish, marine mammals, and birds.

- In the grey and scientific literature, the reef effect is discussed at more length and some of the EIA reports' conclusions are not drawn. Some researchers, for instance, note that even if an artificial reef acts as a fish aggregating device, it can also cause a shift in the equilibrium of the ecosystem due to the replacement of a soft substrate by a hard one [27] [28] [29]. Artificial reefs (piles and foundations) are not the same size or shape as natural reefs [30] and are not aimed at specific ecological restoration. These foundations may not be suitable for the local flora and fauna, especially in the case of soft bottom species as opposed to hard bottom species. A change of pressure inside an ecosystem could, for example, encourage reproduction of opportunistic (native or alien) and potentially invasive species [31]. The food chain can be disturbed and predators attracted [18].

\subsection{Possible explanations for the absence of biodiversity offsets}

Some hypotheses may be suggested to explain why marine biodiversity offsets are not required or not enforced in offshore wind farm deployment projects.

\subsubsection{Technical and ecological explanations of the absence of biodiversity offsets}

No significant negative residual impacts

Residual impacts are not significant because measures for avoiding or reducing environmental offshore impacts have been efficient. In this case ecological offset is unnecessary. This is the main reason put forward in the EIA reports. One research paper claims that offshore wind farm development is not benign for the marine environment but that the impacts are minor and can be mitigated through good siting practices [20]. Another paper notes this consensus in the EIA reports, suggesting that potential negative effects should be predictable and even that many are likely to be minimal or not occur at all (e.g. [32]).

\section{Positive impacts greater than negative impacts}

The second reason put forward by the EIA reports is that positive impacts exceed negative ones. The questions of efficiency and equivalency were discussed in section 4.1. Opinion is divided on whether the various positive impacts claimed in the EIA reports do in fact have a positive impact on marine ecosystems, as this can be a matter of interpretation (e.g. different criteria are used according to countries) or perception [15]. The positive and negative impacts on the marine environment will certainly interact in complex and unpredictable ways" [17]. Another question is: Do wind farm companies give too many marginal" impacts the benefit of the doubt, so as to over-report the number of positive ones?

\section{Negative impacts could be worse than other activities}

Impacts are often compared to other worse impacts of human activities on the environment. For instance, even if offshore wind farms are injurious to marine ecosystems, this may be less severe than biofuels production or biomass use [33] or other human uses of the sea such as trawling (Horns Rev 1, Denmark). Some reports also compare construction work, for instance, to disturbance from natural processes such as storm and flood events (e.g. the London Array wind farm in the UK). One EIA report described what would be the 
effect on the marine environment if the offshore wind farm was not present, for instance describing the effects of global climate change on marine mammals (also the London Array).

\section{The resilience theory}

The resilience of the marine environment is substantial [34]: species recolonize quickly. Some reports argue that weak and limited impacts do not overstep the limits of natural marine dynamics (Egmond aan Zee EIA report). This argument is often put forward to make the few minor negative impacts identified by the EIA reports seem less alarming. But resilience alone is not sufficient and is not the same as the compensation principle. Compensating the negative impacts of human project development cannot be left to nature alone. Also, sensitive habitats and species may not be particularly resilient.

\section{Poor knowledge of the marine environment}

Residual impacts may not be described because of poor knowledge of the marine environment [16] [18] [35]. Even if many studies describe the impacts of offshore wind farms on the environment, the real impacts of the farms on the destruction of ecosystems or on the potential for creating artificial reefs are not clear [15] [17] [36].

\section{Unknown or expensive techniques for marine ecological offsets}

The technical feasibility of implementing ecological offsets in the marine environment seems to be low, and the mean costs of ecological offsets in the marine environment are too high for the moment, particularly for deep sea areas [37]. This is mainly because the knowledge of the marine environment is poor and also because few resources seem to have been devoted to establishing ecological equivalencies in that environment. Developers decide to concentrate on known measures for avoiding and reducing impacts or else to abandon the project.

\subsubsection{Governance and social explanations of the absence of biodiversity offsets}

\section{Reduction or simplification of legal obligations}

Compensation of residual impacts is not mandatory for some Member States who adjusted their legal framework to make it more flexible or who transposed the European Directive with delays (section 3.1). In the German case, this might be due to the political goal of eliminating nuclear energy. In this context, the reduction of the legal obligations might be seen as a way to facilitate the energy transition. The compensation of residual impacts was temporarily not mandatory for some Member States who completely transposed the EIA Directive but with delays, as in the case of Finland where offshore wind farms were not under the jurisdiction of the EIA law until 2011 (section 3.1).

\section{Deficiencies of EU support policies}

Support policies are not clear or do not provide operational guidelines for implementing compensation, in particular with respect to quantitative guidelines [38]. Bruce McKenney [39] notes the need to establish -a clear and defensible process for determining when offsets are an appropriate tool in conformance with the mitigation hierarchy, and when offsets should be rejected in favor of more intensive efforts at steps higher up in the mitigation hierarchy (avoid and minimize)."

\section{Absence of stakeholders in charge of the defense of natural interests}

Regarding power relationships, a stakeholder in charge of the defense of the marine ecosystems that will be impacted is lacking, and it is necessary to go beyond environmental studies in governance [40]. For instance, in the case of the Egmond aan Zee demonstration farm, those who spearheaded the implementation of a compensation plan were an environmental association and an association protesting against the project. More frequent claims by associations defending the marine environment might help to take better 
account of the interests of nature. However, Wolsink [41] points out that not all the stakeholders get a hearing during the EIA process. It is possible that the opinions of stakeholders defending the marine environment are hardly ever heard or taken into account. No perception of underwater impact by the public

The public may not be aware of the underwater impact of offshore wind farms. Many articles deal with the perception of the above-water impact of offshore wind farms, e.g. [42] [43] [44] [45], but few articles deal with the perception of underwater impact. Gee and Burkhard [44] produced an overview of the main arguments raised in opposition to offshore wind farms: their findings showed that the argument primarily raised against offshore wind farms (and often the only one raised) is the fear of negative visual impact above the water.

Trade-off between GHG reduction policy and biodiversity conservation policy

Impacts are acceptable. It can be argued that each project development has impacts but the reason the project is implemented outweighs them. It seems that governments and NGOs, facing a trade-off, decided to support the greenhouse gas reduction policy rather than the biodiversity conservation policy [46] [47]. However, the slowing of climate change and hence reduction of ocean acidification, for instance, could lead to the achievement of some biodiversity conservation aims [48]. If there is a risk of environmental damage due to an overly lax environmental assessment, there is also a risk of slowing down the development of the renewable energy technologies that seem to be necessary to decrease our consumption of conventional energy [15]. Indeed, with a real need to ensure $20 \%$ renewable energy in Europe, it is difficult to oppose this push for -elean" energy and make a persuasive case for the marine environment. Efforts should be devoted to meeting this European standard of $20 \%$ with minimal environmental damage.

\section{Conclusion and recommendations}

The present paper is the only recent scientific study that offers an exhaustive review of offshore wind farm EIA reports. Grey literature about measures taken to deal with the impact of offshore wind farms (or marine renewable energy in general) on the marine environment does exist, but is often general or not exhaustive (studying only a couple of countries, for instance). The scientific literature usually addresses specific impacts, environmental topics, or phases of projects. More general scientific studies address the effect of offshore renewable energy on marine ecosystems, while some are specific to offshore wind farms but are not exhaustive.

The results of the present study indicate that many measures for avoiding or reducing environmental impacts are listed in the EIA reports. Furthermore, developers claim that biodiversity offsets are unnecessary since there are no significant offshore residual impacts. Reports focus on the positive impacts of offshore wind farms, such as the reef effect and reserve effect, rather than on the negative ones. This paper is the first to question explicitly the absence of biodiversity offsets and to propose different explanations for this absence. The legal framework requires adopting the mitigation hierarchy and thus encourages first implementing measures for avoiding and reducing the impacts and only later those for offsetting residual impacts. These findings might be taken to indicate that European regulations have been effective. However, questions remain about the real absence of significant negative residual impacts and the objectivity of other justifications proposed to minimize the impacts or argue that they are benign.

In 2005, Andrew Gill stated that research about new options for offshore renewable energy did not take sufficient account of its ecological consequences [16]. This paper shows that 
things have not changed much since 2005: marine biodiversity is being taken into account, but through an incomplete implementation of the mitigation hierarchy - as long as it is acknowledged that there is something problematic about the claim that offshore wind farm development has no environmental residual impacts with ecological risks [18]. There is a need for more research [17], since knowledge about marine renewable energy technology is increasing while research on its effects on the environment is lagging behind [15]. The legal framework for protecting the environment in the course of infrastructure development cannot be completely implemented and is currently not well adapted to offshore wind farms. The following recommendations describe research priorities necessary to develop and implement meaningful biodiversity offsets in order to fulfill the European aim of $20 \%$ renewable energy with minimal environmental damage.

First, an urgent intensification of research on impacts, cumulative impacts, and ecological restoration techniques on the marine environment is needed, with a stress on long-term analysis now that some wind farms are several decades old. Research is currently still at an early stage and does not provide sufficient experience of undersea biodiversity offsets. Regarding cumulative impacts, particular attention should be given to conducting robust cumulative impact evaluations of several wind farms at the regional level and to the cumulative impacts of multiple turbines in a single array, which are probably undervalued. Recent news about the London Array wind farm shows the incompatibility between the EIA report, which states that the risk of scouring should be addressed by the use of scour protection, and the feedback from local fishers, who report that the entire sediment bed has shifted within and outside the array, completely remaking the benthic habitats and changing fishing grounds permanently [49].

Second, developers should accept their responsibilities and continue their investigations when there is an unknown parameter in the EIA reports. It is important that the precautionary principle should prevail, because it is not sufficient to say that monitoring will be conducted or that knowledge is not available as an excuse to continue impacting the marine environment. Third, two recommendations about the installation of offshore wind turbines in marine ecosystems can be proposed. First, the size, materials, and position of the piles are not properly designed for marine life. The idea that everything that is dropped onto the seabed will quickly be colonized is one example of the common belief in the extreme resilience of the marine environment. In fact, placing objects on the seabed leads to colonization by opportunistic, ubiquitous, and potentially invasive species of low ecological value, such as mussels, sponges, and ascidians, which can disrupt the natural balance of the existing marine ecosystem. Moreover, the use of antifouling and biocide paints, or of smooth concrete on the piles, is inconsistent with the claims about the artificial reef effect. The development of marine life would certainly be more likely on a surface with no harmful components, made of a type of concrete more suitable for marine community colonization, for instance with inlaid fragments of shell or with holes for refuges. Instead of pointing out only the positive consequences of turbines and scour protections, the designers of the piles could adapt them more closely to the local flora and fauna [50] [51]. Second, interim losses are usually not taken into account. The response typically given to this is again that positive impacts globally offset them. But firstly, the amount of both positive and negative impacts is not calculated, so there has probably been no attention to establishing equivalency, and secondly, losses still occur during the period after the damage is caused and before the possible emergence of positive impacts. It is urgent that developers pay more attention to establishing equivalency before any harm is caused, or during the first stages of construction, to address the question of interim losses.

It would be interesting to take advantage of the experience of other offshore industries in the management of impacts on the marine environment. The scientific literature describing impacts caused by the oil and gas offshore industry is substantial [52] [53] [54] [55] [56]. Among them, in the same vein as this paper, is a study on EIA performance carried out for 
this industry [57], specifically for the North Sea, which shows that the way the stakeholders have conducted the EIA studies is questionable. Half of the Environmental Statements were deemed to be of unsatisfactory quality. The study's author particularly underlines the weakness and unreliability of these EIA reports regarding mitigation, alternatives, and cumulative impacts, and refers to other research that draws the same conclusions [58] [59] [60] [61]. It seems that the offshore wind farm industry is not an isolated case.

\section{Acknowledgments}

Our thanks go to Ifremer, Europole Mer, University of Western Brittany and the Brittany region for supporting our work. We would also like to thank the Bioscreen team members for sharing their network of relations with us. For European legal framework information, Juliette Huvet and the EIA/SEA experts of the European Commission were extremely helpful and reliably available. Finally, we thank the anonymous reviewers for their helpful advice.

\section{References}

[1] EWEA. The European offshore wind industry - key trends and statistics 2012. 31 pp.; 2013 Available

from: http://www.ewea.org/fileadmin/files/library/publications/statistics/European_offshore_s tatistics_2012.pdf

[2] Danish Energy Authority. Offshore Wind Farms and the Environment - Danish Experiences from Horns Rev and Nysted, 42 pp.; 2006 . ISBN: 87-7844-620-1. Available from: http://www.nrgenergy.com/pdf/bww/havvindm_korr_16nov_UK.pdf

[3] DONG Energy, Vattenfall, Danish Energy Authority and Danish Forest and Nature Agency. Danish Offshore Wind. Key Environmental Issues. 143 pp.; 2006. ISBN: 877844-625-2. Available from: http://188.64.159.37/graphics/Publikationer/Havvindmoeller/danish_offshore_wind.pdf

[4] Danish Energy Agency. Danish Offshore Wind. Key Environmental Issues - a Follow-up. The Environmental Group: The Danish Energy Agency, The Danish Nature Agency, DONG Energy and Vattenfall, 101 pp.; 2013. ISBN: 978-87-7844-979-5. Available from: http://mhk.pnnl.gov/wiki/images/6/69/Danish_Energy_Agency_2013.pdf

[5] Danish Energy Authority. Offshore Wind Power - Danish Experiences and Solutions, 33 pp.; 2005. ISBN: 87-7844-560-4. Available from:

http://www.offshore-wind.de/page/fileadmin/offshore/documents/Offshore-

Projekte/Offshore_Windpower-_Danish_Experiences_and_Solutions.pdf

[6] Degraer S, Brabant R (Eds.). Offshore wind farms in the Belgian part of the North Sea: State of the art after two years of environmental monitoring. Royal Belgian Institute for Natural Sciences, Management Unit of the North Sea Mathematical Models. Marine ecosystem management unit. 287 pp. + annexes; 2009. Available from: http://www.mumm.ac.be/Assets/Misc/News/monitoring_windmills_2009_final.pdf

[7] Degraer S, Brabant R, Rumes B (Eds.). Offshore wind farms in the Belgian part of the North Sea: Early environmental impact assessment and spatio-temporal variability. Royal Belgian Institute of Natural Sciences, Management Unit of the North Sea Mathematical Models. Marine ecosystem management unit. 184 pp. + annexes; 2010. Available

from: http://www.mumm.ac.be/Downloads/mumm_report_mon_win2010.pdf

[8] Degraer S, Brabant R, Rumes B (Eds.). Offshore wind farms in the Belgian part of the North Sea: Selected findings from the baseline and targeted monitoring. Royal Belgian Institute of Natural Sciences, Management Unit of the North Sea 
Mathematical Models. Marine ecosystem management unit. 157 pp. + annex; 2011. Available from: http://www.mumm.ac.be/Downloads/monwin_report_2011_final.pdf

[9] Degraer S, Brabant R, Rumes B (Eds.). Offshore wind farms in the Belgian part of the North Sea: Heading for an understanding of environmental impacts. Royal Belgian Institute of Natural Sciences, Management Unit of the North Sea Mathematical Models, Marine ecosystem management unit. 155 pp. + annexes; 2012. Available from: http://www.mumm.ac.be/Downloads/News/winmon_report\%202012_cor.pdf

[10] COD. Offshore Wind Energy, Ready to Power a Sustainable Europe, Final Report, Concerted Action on Offshore Wind Energy in Europe; 2001.

[11] COD. Principal findings 2003-2005 - Concerted Action for Offshore Wind Energy Deployment and European Communities; 2005.

[12] COD. Work Package 3 on Legal and Administrative Issues, Concerted Action on Offshore Wind Energy in Europe; 2005.

[13] COD. Work Package 4 on Environmental Issues, Concerted Action on Offshore Wind Energy in Europe; 2005.

[14] Wilhelmsson D, Malm T, Thompson R, Tchou J, Sarantakos G, McCormick N, Luitjens S, Gullström M, Patterson Edwards JK, Amir O, Dubi A. Greening Blue Energy: Identifying and Managing the Biodiversity Risks and Opportunities of Off Shore Renewable Energy. Gland, Switzerland: IUCN; 2010. 102 pp.

[15] Boehlert GW, Gill AB. Environmental and ecological effects of ocean renewable energy development: a current synthesis. Oceanography 2010; 23 (2): 68-81.

[16] Gill $A B$. Offshore renewable energy: ecological implications of generating electricity in the coastal zone. Journal of Applied Ecology 2005; 42 (4): 605-615.

[17] Inger R, Attrill MJ, Bearhop S, Broderick AC, Grecian WJ, Hodgson DJ, Mills C, Sheehan E, Votier SC, Witt MJ, Godley BJ. Marine renewable energy: potential benefits to biodiversity? An urgent call for research. Journal of Applied Ecology 2009; 46 (6): 1145-1153.

[18] Köller J, Köppel J, Peters W. Offshore Wind Energy? Research On Environmental Impacts. Springer-Verlag Berlin and Heidelberg GmbH \& Co. K., Berlin; 2006.

[19] Lindeboom HJ, Kouwenhoven HJ, Bergman MJN, Bouma S, Brasseur S, Daan R, Fijn RC, de Haan D, Dirksen S, van Hal R, Hille Ris Lambers R, de Hofstede R, Krijgsveld $\mathrm{KL}$, Leopold M, Scheidat M. Short-term ecological effects of an offshore wind farm in the Dutch coastal zone: a compilation. Environmental Research Letters 2011; 6: 035101.

[20] Wilson JC, Elliott M, Cutts ND, Mander L, Mendão V, Perez-Dominguez R, Phelps A. Coastal and offshore wind energy generation: is it environmentally benign? Energies 2010 ; 3: 1383-1422.

[21] Rundcrantz K, Skärbäck E. Environmental compensation in planning: a review of five different countries with major emphasis on the German system. European Environment 2003; 13: 204-226.

[22] ten Kate K, Bishop J, Bayon R. Biodiversity Offsets: Views, Experience, and the Business Case. IUCN, Gland, Switzerland and Cambridge, UK and Insight Investment, London, UK. 95 pp.; 2004. Available from: http://cmsdata.iucn.org/downloads/bdoffsets.pdf

[23] European Commission. Report of 23 June 2003 from the Commission to the European Parliament and to the Council on the application and effectiveness of the EIA Directive (Directive 85/337/EEC as amended by Directive 97/11/EC). How successful are the Member States in implementing the EIA Directive? Not published in the Official Journal; 2003. Available at: http://ec.europa.eu/environment/eia/pdf/report_en.pdf

[24] Andersson MH, Berggren M, Wilhelmsson D, Öhman MC. Epibenthic colonization of concrete and steel pilings in a cold-temperate embayment: a field experiment. Helgoland Marine Research 2009; 63 (3): 249-260.

[25] Wilson JC, Elliott M. The habitat creation potential of offshore wind farms. Wind Energy 2009; 12 (2): 203-212. 
[26] Punt MJ, Groeneveld RA, van lerland EC, Stel JH. Spatial planning of offshore wind farms: a windfall to marine environmental protection? Ecological Economics 2009; 69: 93-103.

[27] Bortone SA, Brandini FP, Otake S. Artificial Reefs in Fisheries Management. CRC Press, Taylor and Francis Group, Boca Raton, Florida; 2011.

[28] Spieler RE, Giliam DS, Sherman RL. Artificial substrate and coral reef restoration: what do we need to know to know what we need? Bulletin of Marine Science 2001; 69 (2): 1013-1030(18).

[29] Thanner SE, Mclntosh TL, Blair SM. Development of benthic and fish assemblages on artificial reef materials compared to natural reef assemblages in Miami-Dade County, Florida. Bulletin of Marine Science 2006; 78: 57-70(14).

[30] Krone R, Gutow L, Joschko TJ, Schröder A. Epifauna dynamics at an offshore foundation - implications of future wind power farming in the North Sea. Marine Environmental Research 2013; 85: 1-12.

[31] Sheehy DJ, Vik SF. The role of constructed reefs in non indigenous species introductions and range expansions. Ecological Engineering 2010; 36: 1-11.

[32] Elliott M. The role of the DPSIR approach and conceptual models in marine environmental management: an example for offshore wind power. Marine Pollution Bulletin 2002 ; 44 (6): iii-vii.

[33] Nilsson M, Persson A. Can Earth system interactions be governed? Governance functions for linking climate change mitigation with land use, freshwater and biodiversity protection. Ecological Economics 2012; 75: 61-71.

[34] Jones HP, Schmitz OJ. Rapid recovery of damaged ecosystems. PLoS ONE 2009; 4 (5): e5653.

[35] European Environment Agency. Europe's Onshore and Offshore Wind Energy Potential: An Assessment of Environmental and Economic Constraints, 85 pp.; 2009. ISBN 978-92-9213-000-8 EEA Technical Report series: ISSN 1725-2237.

[36] Burkhard B, Opitz S, Lenhart H, Ahrendt K, Garthe S, Mendel B, Windhorst W. Ecosystem based modeling and indication of ecological integrity in the German North Sea - Case study offshore wind parks. Ecological Indicators 2011; 11 (1): 168-174.

[37] Van Dover CL, Aronson J, Pendleton L, Smith S, Arnaud-Haond S, Moreno-Mateos D, Barbier E, Billett D, Bowers K, Danovaro R, Edwards A, Kellert S, Morato T, Pollard E, Rogers A, Warner R. Ecological restoration in the deep sea: desiderata. Marine Policy 2014; 44 (February): 98-106.

[38] Burgin S. BioBanking: An environmental scientist's view of the role of biodiversity banking offsets in conservation. Biodiversity and Conservation 2008; 17 (4): 807-816.

[39] McKenney BA. Policy development for biodiversity offsets: a review of offset frameworks. Environmental Management 2010; 45 (1): 165.

[40] Hertin J, Turnpenny J, Jordan A, Nilsson M, Russel D, Nykvist B. Rationalising the policy mess? Ex ante policy assessment and the utilisation of knowledge in the policy process. Environment and Planning A 2009; 41 (5): 1185-1200.

[41] Wolsink M. Near-shore Wind power-Protected seascapes, environmentalists' attitudes, and the technocratic planning perspective. Land Use Policy 2010; 27 (2): 195-203.

[42] Wolsink M. Planning of renewables schemes: deliberative and fair decision-making on landscape issues instead of reproachful accusations of non-cooperation. Energy Policy 2007; 35 (5): 2692-2704.

[43] Ladenburg J. Visual impact assessment of offshore wind farms and prior experience. Applied Energy 2009; 86 (3): 380-387.

[44] Gee K, Burkhard B. Cultural Ecosystem services in the context of offshore wind farming: a case study from the west coast of Schleswig-Holstein. Ecological Complexity 2010; 7 (3): 349-358.

[45] Westerberg V, Jacobsen JB, Lifran R. The case for offshore wind farms, artificial reefs and sustainable tourism in the French Mediterranean Tourism Management 2013; 34: 172-183. 
[46] Green R, Vasilakos N. The economics of offshore wind. Energy Policy 2011; 39 (2): 496-502.

[47] Jackson ALR. Renewable energy vs. biodiversity: policy conflicts and the future of nature conservation. Global Environmental Change 2011; 21 (4): 1195-1208.

[48] Parmesan C. Ecological and evolutionary responses to recent climate change. Annual Review of Ecology, Evolution, and Systematics 2006; 37: 637-669.

[49] Offshore Wind Best Management Practices Workshop, Mid-Atlantic Fishery Management Council, February 5-6, 2014, Baltimore, Maryland. Information available at: http://www.mafmc.org/workshop/offshore-wind

[50] Lacroix D, Pioch S. The multi-use in wind farm projects: more conflicts or a win-win opportunity? Aquatic Living Resources 2011; 24 (2): 129-135.

[51] Pioch S, Kilfoyle K, Levrel H, Spieler R. Green marine construction. Journal of Coastal Research 2011; 61 (December): 257-268.

[52] Carr S, Chapman D, Presley B, Biedenbach JM, Robertson L, Boothe P, et al. Sediment porewater toxicity assessment studies in the vicinity of offshore oil and gas production platforms in the Gulf of Mexico: Gulf of Mexico offshore operations monitoring experiment (GOOMEX), Canadian Journal of Fisheries and Aquatic Science 1996; 53(11): 2618-28.

[53] Ducrotoy JP, Elliott M. The science and management of the North Sea and the Baltic Sea: natural history, present threats and future challenges. Marine Pollution Bulletin 2008; 57(1-5):8-21.

[54] Holdway DA. The acute and chronic effects of wastes associated with offshore oil and gas production on temperate and tropical marine ecological processes. Marine Pollution Bulletin 2002; 44(3):185-203.

[55] Huppes G, Davidson MD, Kuyper J, van Oers L, Udo de Haes HA, Warringa G. Ecoefficient environmental policy in oil and gas production in the Netherlands. Ecological Economics 2007; 61:43-51.

[56] Patin S. Environmental impact of the offshore oil and gas industry. East Northport: EcoMonitor Publishing, New York, 1999, 425 pp.

[57] Barker A, Jones C. A critique of the performance of EIA within the offshore oil and gas sector. Environmental Impact Assessment Review 2013; 43 (November): 31-39.

[58] Barker A, Wood C. Evaluation of the performance of the European EIA process. Environmental Impact Assessment Review 1999; 19:387-404.

[59] Canelas L, Almansa P, Merchan M, Cifuentes P. Quality of environmental impact statements in Portugal and Spain. Environmental Impact Assessment Review 2005; 25:217-25.

[60] Nadeem O, Hameed R. A critical review of the adequacy of EIA reports-evidence from Pakistan. International Journal of Humanities and Social Sciences 2006; 1:1-26.

[61] Sandham LA, Pretorius HM. A review of report quality in the North West province of South Africa. Environmental Impact Assessment Review 2008; 28:229-40.

The collected EIA reports are cited in the Appendix. 


\section{Websites}

\section{4coffshore:}

http://www.4coffshore.com/windfarms/

\section{European Wind Energy Association:} http://www.ewea.org/

European Commission website (about Energy): http://ec.europa.eu/energy/renewables/targets_en.htm

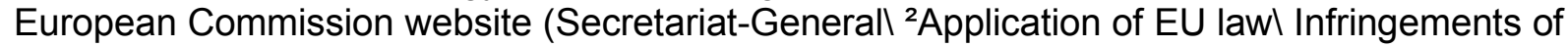
EU law Recent Commission decisions): http://ec.europa.eu/eu_law/infringements/infringements_decisions_en.htm

National Wind Energy Associations:

http://www.iwea.com/ (Ireland), http://www.bwea.com/ (UK), http://www.windpower.org/en/ (Denmark), http://www. wind-energie.de/ (Germany), http://www.vindkraftsbranschen.se/ (Sweden), http://www.nwea.nl/ (Netherlands),

http://users.swing.be/compagnons-eole/windturbine/eole_us.htm (Belgium)

Thewindpower:

http://www.thewindpower.net/windfarms_offshore_en.php 
Appendix: List of offshore wind farms studied and main information

\begin{tabular}{|c|c|c|c|c|c|c|c|c|c|}
\hline Offshore wind farm name & Country & Sea & State & Year & $\begin{array}{l}\mathrm{Nb} \text { of } \\
\text { turbine } \\
\mathrm{s}\end{array}$ & $\begin{array}{l}\text { Capacity } \\
\text { [MW/far } \\
\text { m] }\end{array}$ & \begin{tabular}{|l}
$\begin{array}{l}\text { Foundation } \\
\text { type }\end{array}$ \\
\end{tabular} & $\begin{array}{l}\text { EIA } \\
\text { found }\end{array}$ & How procured \\
\hline Belwind phase I (Bligh Bank) & Belgium & $\begin{array}{l}\text { North } \\
\text { Sea }\end{array}$ & In production & 2010 & 55 & 165 & Monopile & Yes & Internet \\
\hline $\begin{array}{ll}\text { C-Power phase I (Thornton } \\
\text { Bank) }\end{array}$ & Belgium & $\begin{array}{l}\text { North } \\
\text { Sea }\end{array}$ & In production & 2009 & 6 & 30 & Gravity & Yes & Internet \\
\hline C-Power phase II & Belgium & $\begin{array}{l}\text { North } \\
\text { Sea }\end{array}$ & In production & 2012 & 30 & 185 & Jacket & Yes & Internet \\
\hline $\begin{array}{l}\text { C-Power phase III (Thornton } \\
\text { Bank) (same EIA than phase } \\
\text { II) }\end{array}$ & Belgium & $\begin{array}{l}\text { North } \\
\text { Sea }\end{array}$ & $\begin{array}{l}\text { Under } \\
\text { construction }\end{array}$ & $\begin{array}{l}\text { Since } \\
2012\end{array}$ & 18 & 111 & Jacket & Yes & Internet \\
\hline North Wind & Belgium & $\begin{array}{l}\text { North } \\
\text { Sea }\end{array}$ & $\begin{array}{l}\text { Under } \\
\text { construction }\end{array}$ & \begin{tabular}{|l} 
Since \\
2013
\end{tabular} & 72 & 216 & Monopile & Yes & Internet \\
\hline Anholt & Denmark & Kattegat $^{1}$ & In production & 2013 & 111 & 400 & Monopile & Yes & Internet \\
\hline Horns Rev 1 & Denmark & $\begin{array}{l}\text { North } \\
\text { Sea }\end{array}$ & In production & 2002 & 80 & 160 & Jacket & Yes & Internet \\
\hline Horns Rev 2 & Denmark & $\begin{array}{l}\text { North } \\
\text { Sea }\end{array}$ & In production & 2009 & 91 & 209 & Monopile & Yes & Internet \\
\hline Middelgrunden & Denmark & Kattegat $^{1}$ & In production & 2000 & 20 & 40 & Gravity & Yes & Internet \\
\hline Nysted (Rodsand I) & Denmark & $\begin{array}{l}\text { Baltic } \\
\text { Sea }\end{array}$ & In production & 2003 & 72 & 166 & Gravity & Yes & Internet \\
\hline Nysted (Rodsand II) & Denmark & $\begin{array}{l}\text { Baltic } \\
\text { Sea }\end{array}$ & In production & 2010 & 90 & 207 & Gravity & Yes & Internet \\
\hline Sams $\varnothing$ (Paludans Flak) & Denmark & Kattegat $^{1}$ & In production & 2003 & 10 & 23 & Monopile & $\mathrm{Yes}^{2}$ & Internet \\
\hline Store Baelt (Sprogø) & Denmark & Kattegat $^{1}$ & In production & 2009 & 7 & 21 & Gravity & Yes & Internet \\
\hline Tunø Knob & Denmark & Kattegat $^{1}$ & In production & 1995 & 10 & 5 & Gravity & No & -- \\
\hline Vindeby-Lolland & Denmark & Kattegat $^{1}$ & In production & 1991 & 11 & 5 & Gravity & No & -- \\
\hline Alpha Ventus & Germany & $\begin{array}{l}\text { North } \\
\text { Sea }\end{array}$ & In production & 2009 & 12 & 60 & $\begin{array}{l}\text { Tripod, } \\
\text { jacket }\end{array}$ & $\mathrm{Yes}^{2}$ & Internet \\
\hline Baltic 1 & Germany & $\begin{array}{l}\text { Baltic } \\
\text { Sea }\end{array}$ & In production & 2011 & 21 & 48 & Monopile & No & -- \\
\hline Amrum Bank West & Germany & $\begin{array}{l}\text { North } \\
\text { Sea }\end{array}$ & $\begin{array}{l}\text { Under } \\
\text { construction }\end{array}$ & $\begin{array}{l}\text { Since } \\
2013\end{array}$ & 80 & 288 & Monopile & $\mathrm{Yes}^{2}$ & Internet \\
\hline
\end{tabular}




\begin{tabular}{|c|c|c|c|c|c|c|c|c|c|}
\hline Bard Offshore 1 & Germany & $\begin{array}{l}\text { North } \\
\text { Sea }\end{array}$ & $\begin{array}{l}\text { Under } \\
\text { construction }\end{array}$ & $\begin{array}{l}\text { Since } \\
2011\end{array}$ & 80 & 20 & Tripile & Yes $^{2}$ & Scans sent \\
\hline Borkum Riffgat & Germany & $\begin{array}{l}\text { North } \\
\text { Sea }\end{array}$ & $\begin{array}{l}\text { Under } \\
\text { construction }\end{array}$ & $\begin{array}{l}\text { Since } \\
2012\end{array}$ & 30 & 108 & Monopile & No & -- \\
\hline Borkum West II (phase I) & Germany & $\begin{array}{l}\text { North } \\
\text { Sea }\end{array}$ & $\begin{array}{l}\text { Under } \\
\text { construction }\end{array}$ & $\begin{array}{l}\text { Since } \\
2011\end{array}$ & 80 & 400 & Tripod & Yes & Scans sent \\
\hline Dan Tysk & Germany & $\begin{array}{l}\text { North } \\
\text { Sea }\end{array}$ & $\begin{array}{l}\text { Under } \\
\text { construction }\end{array}$ & $\begin{array}{l}\text { Since } \\
2013\end{array}$ & 80 & 288 & Monopile & Yes $^{2}$ & Internet \\
\hline Global Tech 1 & Germany & $\begin{array}{l}\text { North } \\
\text { Sea }\end{array}$ & $\begin{array}{l}\text { Under } \\
\text { construction }\end{array}$ & $\begin{array}{l}\text { Since } \\
2012\end{array}$ & 80 & 400 & Tripod & Yes $^{2}$ & Internet \\
\hline Meerwind Ost/SUD & Germany & $\begin{array}{l}\text { North } \\
\text { Sea }\end{array}$ & $\begin{array}{l}\text { Under } \\
\text { construction }\end{array}$ & $\begin{array}{l}\text { Since } \\
2012\end{array}$ & 80 & 288 & Monopile & Yes $^{2}$ & Internet \\
\hline Nordsee Ost & Germany & $\begin{array}{l}\text { North } \\
\text { Sea }\end{array}$ & $\begin{array}{l}\text { Under } \\
\text { construction }\end{array}$ & $\begin{array}{l}\text { Since } \\
2012\end{array}$ & 48 & 295 & Jacket & Yes $^{2}$ & Internet \\
\hline Arklow Bank & Ireland & Irish Sea & In production & 2003 & 7 & 25 & Monopile & Yes & $\begin{array}{l}\text { Documents } \\
\text { emailed }\end{array}$ \\
\hline Egmond aan Zee (OWEZ) & $\begin{array}{l}\text { Netherland } \\
\mathrm{s}\end{array}$ & $\begin{array}{l}\text { North } \\
\text { Sea }\end{array}$ & In production & 2006 & 36 & 108 & Monopile & Yes & Internet \\
\hline Prinses Amalia (Q7) & $\begin{array}{l}\text { Netherland } \\
\mathrm{S}\end{array}$ & $\begin{array}{l}\text { North } \\
\text { Sea }\end{array}$ & In production & 2008 & 60 & 120 & Monopile & Yes & Internet \\
\hline Bockstigen Offshore & Sweden & $\begin{array}{l}\text { Baltic } \\
\text { Sea }\end{array}$ & In production & 1998 & 5 & 3 & Monopile & Yes & Scans sent \\
\hline Lillgrund & Sweden & $\varnothing_{\text {resund }}^{1}$ & In production & 2008 & 48 & 110 & Gravity & Yes & $\begin{array}{l}\text { Documents } \\
\text { emailed }\end{array}$ \\
\hline Utgrunden I & Sweden & $\begin{array}{l}\text { Baltic } \\
\text { Sea }\end{array}$ & In production & 2000 & 7 & 11 & Monopile & No & -- \\
\hline Yttre Stengrund 1 & Sweden & $\begin{array}{l}\text { Baltic } \\
\text { Sea }\end{array}$ & In production & 2001 & 5 & 10 & Monopile & No & -- \\
\hline Kårehamn & Sweden & $\begin{array}{l}\text { Baltic } \\
\text { Sea }\end{array}$ & $\begin{array}{l}\text { Under } \\
\text { construction }\end{array}$ & $\begin{array}{l}\text { Since } \\
2012\end{array}$ & 16 & 48 & Gravity & No & - \\
\hline Barrow & UK & Irish Sea & In production & 2006 & 30 & 90 & Monopile & Yes & Internet \\
\hline Burbo Bank & UK & Irish Sea & In production & 2007 & 25 & 90 & Monopile & Yes & Internet \\
\hline Greater Gabbard & UK & $\begin{array}{l}\text { North } \\
\text { Sea }\end{array}$ & In production & 2012 & 140 & 504 & Monopile & Yes & Internet \\
\hline Gunfleet Sands (phase I and & UK & North & In production & 2010 & 48 & 173 & Monopile & Yes & Internet \\
\hline
\end{tabular}




\begin{tabular}{|c|c|c|c|c|c|c|c|c|c|}
\hline II) & & Sea & & & & & & & \\
\hline Kentish Flats & UK & $\begin{array}{l}\text { North } \\
\text { Sea }\end{array}$ & In production & 2005 & 30 & 90 & Monopile & Yes & Internet \\
\hline London Array Phase I & UK & $\begin{array}{l}\text { North } \\
\text { Sea }\end{array}$ & In production & 2013 & 175 & 630 & Monopile & Yes & $\begin{array}{l}\text { Documents } \\
\text { emailed }\end{array}$ \\
\hline Lynn and Inner Dowsing & UK & $\begin{array}{l}\text { North } \\
\text { Sea }\end{array}$ & In production & 2009 & 54 & 194 & Monopile & Yes & Internet \\
\hline North Hoyle & UK & Irish Sea & In production & 2003 & 30 & 60 & Monopile & Yes & Internet \\
\hline Ormonde & UK & Irish Sea & In production & 2011 & 30 & 150 & Jacket & Yes & Internet \\
\hline Rhyl Flats & UK & Irish Sea & In production & 2009 & 25 & 90 & Monopile & No & -- \\
\hline Robin Rigg & UK & Irish Sea & In production & 2010 & 60 & 180 & Monopile & Yes & $\begin{array}{l}\text { Documents } \\
\text { emailed }\end{array}$ \\
\hline Scroby Sands & UK & $\begin{array}{l}\text { North } \\
\text { Sea }\end{array}$ & In production & 2004 & 30 & 60 & Monopile & Yes $^{2}$ & Scans sent \\
\hline Sheringham Shoal & UK & $\begin{array}{l}\text { North } \\
\text { Sea }\end{array}$ & In production & 2013 & 88 & 317 & Monopile & Yes & Internet \\
\hline Thanet & UK & $\begin{array}{l}\text { North } \\
\text { Sea }\end{array}$ & In production & 2010 & 100 & 300 & Monopile & Yes & Internet \\
\hline Walney (phase I and II) & UK & Irish Sea & In production & $\begin{array}{l}2011 \quad(\mathrm{I}) \\
2012 \text { (II) }\end{array}$ & 102 & 368 & Monopile & Yes & Internet \\
\hline Gwynt y Mor & UK & Irish Sea & $\begin{array}{l}\text { Under } \\
\text { construction }\end{array}$ & $\begin{array}{l}\text { Since } \\
2012\end{array}$ & 160 & 576 & Monopile & Yes & Internet \\
\hline Lincs & UK & $\begin{array}{l}\text { North } \\
\text { Sea }\end{array}$ & $\begin{array}{l}\text { Under } \\
\text { construction }\end{array}$ & $\begin{array}{l}\text { Since } \\
2011\end{array}$ & 75 & 270 & Monopile & Yes & $\begin{array}{l}\text { Documents } \\
\text { emailed }\end{array}$ \\
\hline Teesside & UK & $\begin{array}{l}\text { North } \\
\text { Sea }\end{array}$ & $\begin{array}{l}\text { Under } \\
\text { construction }\end{array}$ & $\begin{array}{l}\text { Since } \\
2012\end{array}$ & 27 & 62 & Monopile & Yes & Internet \\
\hline West of Duddon sands & UK & Irish Sea & $\begin{array}{l}\text { Under } \\
\text { construction }\end{array}$ & $\begin{array}{l}\text { Since } \\
2013\end{array}$ & 108 & 389 & Monopile & Yes $^{2}$ & Internet \\
\hline
\end{tabular}

${ }^{1}$ The Kattegat is between the North Sea and the Baltic Sea; the Øresund is between the Kattegat and the Baltic Sea. ${ }^{2}$ Only extracts or summaries of other files with main information were found. 